\title{
Francesc Massip Bonet (ed.), Repensar el sombrío Medioevo / Those Dark Ages Revisited. Nuevas perspectivas para el estudio de la cultura medieval y de la temprana Edad Moderna, Kassel, Edition Reichenberger, 2014, 245 pp.
}

Viviendo en una época tecnológicamente avanzada, tan alejada de la Edad Media, tan aparentemente ajena a la Edad Media, hay que reconocer que al igual que en aquel tiempo sigue habiendo conflictos, desigualdad social y diásporas, porque probablemente nuestra mentalidad, nuestra forma de pensar, no ha cambiado tanto a través del transcurso del tiempo. Sin embargo, se tiende a ver la Edad Media como la Edad Oscura, una época remota e incomprensible. Este libro demuestra lo contrario: fue una época calidoscópica, fecunda, llena de matices, que nos sorprende pero entendible desde nuestro tiempo.

El volumen es una selección de estudios interdisciplinares sobre la cultura medieval que abarca cuatro ámbitos: las artes plásticas, las artes escénicas, los estudios de género y la creación literaria. Se trata de las últimas pesquisas que se han llevado a cabo dentro del Grupo de Investigación LAiREM (Literatura, Arte y Representación en la larga Edad Media). El libro no intenta repetir ni mostrar aspectos ya estudiados sino que se focaliza en elementos que a veces han resultado borrosos y explora documentos que no han sido valorados suficientemente. También se aventura en indagar como un caballero andante, con nuevas estrategias de estudio.

Tras una presentación esmerada del editor que abre el volumen, siguen tres estudios sobre las artes plásticas. El primero es de Licia Buttà, quien cuestiona y reflexiona sobre el papel de la red y las nuevas tecnologías de informática en el estudio de la historia del arte. Es acertada su propuesta de "perfilar nuevas perspectivas, renovar las preguntas e incentivar las respuestas sobre una época en la que se hunden las raíces mismas de la modernidad», si no, se estanca uno en el mismo conocimiento por la sobrecarga de información. El segundo es sobre la voz de lo ridículo que aparece en los textos medievales, de Daniel Rico, quien argumenta citando a Cicerón, su efectividad para reforzar la idea central, es decir, lo sagrado. Respecto a textos con imágenes e iconografía, mostrando algunos ejemplos, plantea la necesidad de catalogarlos. El tercero, de Eduardo Carrero, nos ofrece un análisis minucioso de la pintura tardogótica de La presentación de la Virgen de Pieter Claessens el Viejo de la iglesia de Sint-Jacobskerk de Brujas (Bélgica). Dada la obsesión de los pintores de la época por representar la realidad, las imágenes de la pintura no solo sirven para reconstruir históricamente la arquitectura de la iglesia, la vida cotidiana de los nobles, el mobiliario o el vestido, sino también para la puesta en escena de la Presentación de la Virgen que posiblemente fuera representada. Curiosísima la observación de Carrero, acerca 
del actor que llegando tarde al acontecimiento, cambiándose de ropa y con disfraz femenino, dirige una mirada al público. Sería interesante conocer la razón por la cual el pintor decidió recrear ese preciso momento de la escena.

El segundo apartado, de artes escénicas, viene encabezado por el estudio de Francesc Massip, erudito de la Historia de Teatro, sobre todo de las épocas medieval y renacentista. Dada la peculiaridad efímera de las artes escénicas, las obras iconográficas suelen ser utilizadas y analizadas como una de las pocas posibilidades de dar forma perdurable a la representación escénica y su dramaturgia. No obstante, esta vez su objetivo no es analizar obras iconográficas para reconstruir una historia escénica concreta sino que nos presenta nuevas metodologías, a la hora de estudiar artes escénicas o espectáculos de la época que nos interese, a partir de la iconografía: clasifica las obras iconográficas como testimonios teatrales en siete tipos de documentos. Esta clasificación seguramente favorecerá como nueva herramienta a los historiadores de teatro. Sin embargo, hay que andar con cautela porque no siempre es fiable la iconografía como documento histórico para el estudio analítico del teatro, como lo demuestra Sandra Pietrini en el siguiente estudio. Según la autora, quien analiza la iconografía (miniaturas y xilografías) que acompaña a los textos terencianos, aunque la iconografía del siglo XVI se aproxima gradualmente a una puesta en escena verosímil, no debemos apresurarnos a deducir hipótesis de reconstrucción escénica, ya que la génesis de una forma iconográfica es mucho más complicada. No sólo deriva «de la realidad y de la práctica escénica, sino de una combinación de la observación de los espectáculos contemporáneos y de la memoria culta del teatro, construida a partir de palabras». Por otro lado, Óscar Armando García nos transporta a través de su estudio sobre la fiesta de locos a América. Una fiesta invernal, saturnal, pero de raigambre medieval, que sobrevive por «la posibilidad de tener un foro libre de expresión crítica, a través de la inversión» y que la fiesta sea "un afortunado punto de encuentro por parte de las comunidades para su regocijo y para fomentar la burla hacia lo establecido". El autor subraya la importancia de la pieza dramática titulada Todos contra el payo y el payo contra todos o la visita del payo en el Hospital de Locos, atribuida a José Joaquín Fernández Lizardi (I776-I82I), y la «Danza de los Ocho Locos» que aún se celebra en Chilapa, Guerrero (México). Sería interesante que hiciera un estudio comparativo más exhaustivo de aquella obra dramática y de esta «Danza de los Ocho Locos».

El tercer bloque, sobre estudios de género, es una novedad dentro de este volumen. Estudios de género, tanto de historia como de literatura, sobre todo de mujeres, que suelen ser independientes, ramas que en las últimas décadas han empezado a ser exploradas con notoriedad. Gracias a ese impulso por la investigación del género de lo femenino, la figura de la mujer se ha vuelto visible. Pero la mera visibilidad no tiene 
valor si no se describe dentro de la historia. De este libro, sobre estudios medievales, se ha de valorar el hecho de que incluya temas femeninos que indagan sobre la participación de la mujer medieval en la producción y el consumo de las artes y las letras de dicha época. Almudena Blasco Vallés que abre este apartado, intenta definir el proceso de creación de los modelos del femenino social a finales de la Edad Media, analizando diversos tipos de fuentes: doctrinales, literarias e iconográficas. Nos demuestra por una parte cómo el doctrinal de la Iglesia impone un ideal de mujer sumisa y devota, y por otra, cómo el cortesano genera una moda en la alta sociedad gracias a la revolución comercial que se va cuajando en la vida mundana a través de las fiestas caballerescas. El segundo trabajo, de Lenke Kovács, analiza algunos personajes femeninos que aparecen en las piezas dramáticas conservadas en el manuscrito Llabrés, que se representaban en las iglesias de Mallorca: Susana, Judit, Esther, heroínas del Antiguo Testamento, María en las piezas navideñas y de la Pasión, santas como Ágata o Eulalia, patrona de Barcelona. La última aportación de este apartado es de Rebeca Sanmartín, sobre una "self starving woman», escritora cisterciense llamada María Vela y Cueto (I56I-I6I7). Se trata de una "visionaria» que aspiraba a ser santa a través de ayunos muy severos y arriesgados, intentando no solo situarla «en el entendimiento histórico del ayuno femenino", sino también llegar a comprender el concepto médico de la anorexia.

El apartado literario es encabezado por el estudio de Anton Espadaler i Poch, sobre un poema caballeresco, una composición del trovador catalán Raimon Vidal de Besalú So fo e.l temps com era gais, en la cual un caballero que esperaba recibir la recompensa amorosa es rechazado por una dama, después de haberle servido durante siete años. Enfoca su análisis sobre el debate de si una dama de alto nivel debiera conceder esa recompensa sexual a un caballero de nivel inferior, o si el servicio exigiese total renuncia y obediencia a la dama. Sigue el excelente trabajo de Donatella Siviero que analiza algunas obras narrativas de la Castilla medieval que incluyen el tema del viaje, tales como El caballero Zifar, Embajada a Tamorlán, Libro del conosçimiento, El Victorial, Tratado de andanzas y viajes. Mientras los historiadores intentan describir hechos reales, los novelistas se empeñan en «autentificar como verdades sus ingredientes ficcionales». La autora llega a la conclusión de que en ambos géneros los textos utilizan las mismas estrategias y recursos de autentificación de la realidad. Lo real maravilloso, como decía Carpentier, ya existía en la narrativa medieval. Llívia Palliso, con el estudio sobre La Faula de Torroella, cierra el volumen. La autora argumenta que la obra podría tener un fin de propaganda, o ser una reinvindicación de los derechos de la familia real mallorquina suplantada por el rey Pere el Cerimoniós en la batalla de Llucmajor.

El libro, con sus doce estudios que abarcan cuatro diferentes gamas, es una guía excepcional para conocer nuevas perspectivas en estudios medievales. Se ha de 
valorar también la inserción de numerosas ilustraciones que ayudan a complementar el conocimiento. Con ellas se facilita nuestra capacidad imaginativa para entrar en el mundo creativo de los hombres y mujeres de hace siglos. Es sugestivo también que no se limita a Espańa como ámbito geográfico a investigar sino que se trasciende a todo el territorio de la "Romania», e incluso a América donde quedan sus huellas. Es donde se percibe tanto la cultura globalizada que existía en la Edad Media como la diversidad dentro de un territorio determinado.

\section{Hiroco Karilla}

Meiji University

School of Political Science and Economics, Japó 